\title{
Mining Plants for Biodiesel in China
}

\section{LONG Chunlin ${ }^{1,2, a}$, YANG Jun ${ }^{2, b}$, WANG Zhi ${ }^{2,3, c}$ and MA Lijuan ${ }^{1,4, d}$}

${ }^{1}$ College of Life and Environmental Sciences, Minzu University of China. Beijing 100081, China

${ }^{2}$ Kunming Institute of Botany, Chinese Academy of Sciences. Kunming 650201, China

${ }^{3}$ College of Pharmacy, Hunan University of Chinese Medicine. Changsha 410208, China

${ }^{4}$ Institute of Chinese Medical Science, University of Macau. Taipa, Macau, China

a long.chunlin@muc.edu.cn, b yangjuna@mail.kib.ac.cn, ${ }^{\text {c } z h i w 5202004 @ 126 . c o m, ~}{ }^{d}$ maljsmile@126.com

* corresponding author: C. L. Long, Ph.D., Professor. Tel: +86-10-6893-0381

\section{Keywords: Biodiesel; Oil analysis; Seed plant; Species diversity; Yunnan}

Abstract: It has become an action plan to develop biodiesel in China. The botanical and laboratory investigations together with literature surveys had been used to prospect potential plants for biodiesel development. Based on field surveys and collections of specimens and samples, 422 oil-bearing plant species had been documented from Yunnan, the richest province with plant species diversity in the country. The oil content, acid value, iodine value, saponification value, and fatty acid composition of plant samples had been tested and assessed. The results revealed that Camellia oleifera var. monosperma, Michelia sphaerantha, Euonymus tingens, Daphniphyllum paxianum, Trichosanthes rubriflos, Symplocos chinensis and Daphniphyllum macropodum might be selected as the potential plant species for biodiesel development in China.

\section{Introduction}

Biodiesel is made from biological resources including plant oils, recycled cooking oil and animal fats. It is regarded as a renewable, clean and safe diesel. The biodiesel transesterified from plant (seeds, fruits or other organs) oils becomes more and more acceptable nowadays [1].

According to the official website of National Biodiesel Board, the national trade association representing the biodiesel industry in the United States of America (http://biodiesel.org/) [2], the biodiesel industry has steadily grown over the past decade, with commercial production facilities from coast to coast. The industry has reached more than 1 billion gallons since 2011. It has provided more than 62,200 jobs nationwide. Biodiesel reduces greenhouse gas emissions by $57 \%$ to $86 \%$ in the United States.

In China, the research and development of plant-based biodiesel has been initiated since 1980s, represented by a key project supported by the Chinese Academy of Sciences. In 2004 a number of big projects were released by the Commission of Development and Innovation, and the Ministry of Science and Technology, to improve the technical developments of biodiesels in the country. Later some species such as Jatropha curcas, Camellia oleifera, Pistacia sinensis, Vernicia fordii, and other high-yielded oil-bearing woody plants have been cultivated in a large scale, with supports from central and provincial governments in China. In particular, China issued an important announcement to accelerate the development of oil-bearing woody plants on January 13, 2015 [3]. According to the announcement, China will finish the establishment of 800 remarkable counties with Camellia oleifera, Juglans regia, oil peonies and others by the end of 2020. The central government will lead a nation-wide germplasm investigation of oil-bearing woody plants including Juglans regia, oil peonies, olive, Amygdalus pedunculatus, Swida wilsoniana, Acer truncatum, Elaeagnus mollis, Eucommia ulmoides, Rhus chinensis, Xanthoceras sorbifolium and others. It has provided strong policy, financial and technical supports to the development of food oil and biodiesel enterprises in the country [3].

In this paper, we try to reveal the status of germplasm resources of oil-bearing plants in China based on our studies in the past a few years. Yunnan Province has been studied as a case site in the present 
paper. The characteristics of oil-bearing plants will be analyzed according to the national standards, including oil content, acid value, iodine value, saponification value, and composition of fatty acid. Results from this study will be helpful for future development of biodiesels from plants in China, especially the selection of oil-bearing woody species for plantations, and for new variety breeding in the near future.

\section{Methods}

\section{Data Collection.}

In recent years, our group had worked on biodiesel plants and published a book entitled China's Biodiesel Plants [1][4-12], together with papers. We have checked all scientific studies published in journals, books, theses and reports related to biodiesel plants in China. Pertinent literature was searched in different electronic databases (ISI Web of Science, Wanfang Data, VIP Information, Science Direct, and Google Scholar) using specific search terms such as "oil-bearing plants", "fatty acids from plants", "biodiesel", and combined with geographical names: "China", "Yunnan", "Southern China" or other names such as "policy", "plantation", and etc.

\section{Field Investigation.}

We have conducted field surveys since 2005 focusing on southwest China, especially Yunnan Province. Information related to indigenous knowledge of oil-bearing plants had been investigated in villages through ethnobotanical methods. Specimens were collected and identified based on taxonomical approaches. The identification of difficult taxa was confirmed by experts. Samples for analyzing composition of fatty acids were also collected from the fields. Most of them were seeds, and some were fruits or other organs of plants. The oil-bearing seed plant species collected from Yunnan had been documented.

\section{Laboratory Experiment.}

Equipments such as Angilent GC6890N, Buchi R-3 rotary evaporators and Soxhlet extractor were used in the study [4]. We have extracted fatty acids and examined contents of oil according to the national standard numbered GB/T5512-2008. Other national standards namely GB/T 5530-1985, GB/T 5532-2008 and GB/T 5534-2008 were applied for examination of acid value, iodine value, and saponification value, respectively. Agents including hexane, methanol, $\mathrm{KOH}$, magnesium oxide, anhydrous sodium sulfate, and others were used in the experiment [5].

\section{Results}

\section{Species Diversity.}

There are rich plant resources for biodiesel development in China, including wild and cultivated plants. Among its 34,000 species of higher plants, China has more than 1,500 species of oil-bearing plants, in which some species can be developed for biodiesel production [1].

Yunnan is regarded as the richest province in biodiversity in China. Over 15,000 seed plant species had been recorded in the province, which occupies almost $50 \%$ of the whole flora of China although its territory is only $4 \%$ of the country's terrestrial area [13]. The oil-bearing plants occurring in Yunnan were investigated. In total 422 plant species had been collected and documented. They belong to 95 families and 259 genera. Those families with at least 10 species of oil-bearing plants are: Rosaceae (31 spp.), Euphorbiaceae (26 spp.), Rutaceae (21 spp.), Leguminosae (20 spp.), Lauraceae (18 spp.), Cucurbitaceae (17 spp.), Magnoliaceae (16 spp.), Theaceae (14 spp.), Anacardiaceae (12 spp.), Oleaceae (12 spp.), Meliaceae (11 spp.), Rhanaceae (11 spp.), Caprifoliaceae (10 spp.) and Palmae (10 spp.).

Most oil-bearing plant species in Yunnan are distributed in the areas less than 3,000 meters above sea level. The common woody species include: Pinus armandii, Cephalotaxus sinensis, Litsea cubeba, Camellia sinensis, $C$. pitardii, $C$. reticulata, C. oleifera, C. sinensis var. assamica, Sloanea hemsleyana, Mallotus tetracoccus, Ostodes katharinae, Sapium discolor, S. sebiferum, Vernicia fordii, Jatropha curcas, Prinsepia utilis, Cerasus cerasoides, Armenia cavulgaris, Prunus salicina, 
Daphniphyllum paxianum, Corylus yunnanensis, Celastrus angulatus, Euonymus grandifrus, E. tingens, Evodia trichotoma, Citrus maxima, Toona sinensis, Sapindus delavayi, Pistacia chinesis, Toxicodendron vernicifluum, Juglans regia, J. sigillata, Bothrocaryum controversum, Acanthopanax trifoliatus, Clerodendrum trichotomum, Symplocos paniculata and S. chinensis.

\section{Plantations of Oil-bearing Plants.}

The mountainous areas suitable for biodiesel plant plantations reach 4,980,000 $\mathrm{km}^{2}$ which occupies $51.8 \%$ of China's territory. In particular, over 650 million hectares of lands will be used for afforestation. If $10 \%$ of these lands could be covered with oil-bearing woody plants, the oil production would be more than 97.5 millions of tons per year [1]. Since 2003, the country has planned to support and develop biodiesel. By the end of 2015, the total plantation areas of oil-bearing plants will reach 1.67 million hectares. The yield of oil will be one million tons.

Soybean, rape seeds, sunflower, and castor bean (Ricinus communis) are traditional oil-bearing crops in China. Over 30 species of arbors and shrubs have been cultivated in China, including Jatropha curcas, Pistacia chinesis, Camellia oleifera, Vernicia fordii, Xanthoceras sorbifolium, Sindora glabra, Euphorbia tirucalli, and Swida wilsoniana. Most of them are grown in the tropical and subtropical regions such as Yunnan and Guangxi [14]. Only a few species were recognized as targeted non-food woody plants to be extended in the county, such as Jatropha curcas, Pistacia chinesis, and Vernicia fordii. In China, due to the concern over rising food and fuel prices, the State Council ruled in June 2007 to prohibit the production of biofuel from grain-based feedstocks and encouraged the growth of jatropha and other woody oil-bearing plants due to its perceived ability to grow on marginal lands unsuitable for food production.

Among all non-food plants, Jatropha curcas is a star species in all cultivated oil-bearing plants in China. The oil from jatropha is regarded as a potential fuel substitute. The plant oils are usually trans-esterised (with alcohol and hydroxide) to biodiesels with properties similar to mineral diesel [15]. To compare with the oil from other species, the transformation costs from jatropha oil are the lowest one. Therefore, PetroChina is working actively with State Forestry Administration and provincial governments to development jatropha production in Yunnan and Sichuan provinces. The total plantation areas reached 100,000 hectares in Yunnan Province by the end of 2013.

The Vernicia fordii plantations are also very big in China, covering an area of 661,700 hectares with an average yearly-yield of oil at 67,500 tons. Guangxi is the largest zone of Vernicia plantations, with an area of 161,200 hectares and yielding 20,000 tons of oil. Guizhou Province takes the second rank by its plantation area of 157,400 hectares and 16,000 tons of oil. The third largest province is Chongqing for its cultivation area of about 100,000 hectares and 16,000 tons of oil from Vernicia [16]. In Hunan Province, Vernicia plantations have a very long history with higher quality and yields.

\section{Analysis of Oils.}

The oil content, acid value, iodine value, saponification value, and fatty acid composition of plant samples collected from Yunnan have been analyzed. Most samples are seeds, only a few are fruits or other organs.

The oil contents varied from $0.20 \%$ to $71.00 \%$, and showed huge difference among samples. About $45 \%$ of samples reached a higher oil contents (>30\%). These samples were mainly from Lauraceae, Euphorbiaceae, and Magnoliaceae. Samples from 25 species contained the highest oil contents (> 50\%). Examples included Juglans, Myrica, Vernicia, Camellia and Canarium.

The acid values varied from 0.16 to $185.80 \mathrm{mgKOH} / \mathrm{g}$, and showed big difference from one sample to another. In general, samples from Rosaceae, Juglandaceae and Theaceae showed lower acid values. When the acid values are less than $5.00 \mathrm{mgKOH} / \mathrm{g}$, the oils are regarded as appropriate for biodiesel. About $60 \%$ of samples met this criterion. Most of them are from Euphorbiaceae, Cucurbitaceae, Rosaceae, Theaceae, Lauraceae and Juglandaceae.

The iodine values varied from 1.80 to $204.69 \mathrm{mgI}_{2} / \mathrm{g}$. They showed big difference from one sample to another. The iodine values between 50.00 and $125.00 \mathrm{mgI}_{2} / \mathrm{g}$ are suitable for biodiesel. About $63 \%$ 
of samples met this criterion. Most samples are from Cucurbitaceae, Rutaceae, Rosaceae, Magnoliaceae, Euphorbiaceae, and Theaceae.

The saponification values of most samples were between 175.00 and $200.00 \mathrm{mgKOH} / \mathrm{g}$. There were less different from one family to another. Only Lauraceae showed higher saponification value at about 180.00. The saponification values of $175.00 \sim 200.00 \mathrm{mgKOH} / \mathrm{g}$ are good for biodiesel. About $70 \%$ of samples met this criterion.

The compositions of fatty acids differed from one species to another, with 5-12 types of fatty acids. Most fatty acids extracted from the samples contained 10-20 carbon atoms per molecule. Plants with more than $40 \%$ of saturated fatty acids in the samples were represented by 39 species. They were from Lauraceae, Rutaceae, and Palmae. The contents of bay acid and decanoic acid could be as high as $90 \%$ in Cinnamomum camphora, $C$. glanduliferum and C. parthenoxy samples. The contents of mono unsaturated fatty acids with more than $40 \%$ were found in 107 species, mainly belonging to Theaceae, Rosaceae, Cornaceae and Oleaceae. In the samples of Aucuba chlorascens and A. chlorascens, for example, over $90 \%$ were mono unsaturated fatty acids. The contents of polyunsaturated fatty acids with more than $40 \%$ were detected from 129 species, mainly from Euphorbiaceae, Myricaceae, Pinaceae, Fabaceae, Asteraceae, Cucurbitaceae, Juglandaceae, Rosaceae, Ulmaceae, Magnoliaceae, and Labiatae. Examples include Xanthium sibiricum, Perilla frutescens, and Celtis tetrandra.

\section{Summary}

Biodiesel from seed plants is regarded as green, clean and renewable energy. Based on field investigations and laboratory studies, the species for biodiesel had been documented and their values had been evaluated. Over 1,500 seed plant species had been recorded as oil-bearing plants in China. Jatropha curcas and Vernicia fordii are the most important species for biodiesel plantations in the country. We collected and documented 422 oil-bearing plant species from Yunnan although its area is only $4 \%$ of the country's territory. The oil content, acid value, iodine value, saponification value, and fatty acid composition of plant samples collected from Yunnan had been analyzed and evaluated. According to our evaluation, seven species are regarded as the best candidates for future development. They are Camellia oleifera var. monosperma, Michelia sphaerantha, Euonymus tingens, Daphniphyllum paxianum, Trichosanthes rubriflos, Symplocos chinensis and Daphniphyllum macropodum.

\section{Acknowledgements}

We are grateful to the colleagues and students at the Ethnobotanical Laboratory of Minzu University of China and Kunming Institute of Botany for their participating in field investigation, sample-collecting, and helpful comments and discussions. This work was financially supported by the National Natural Science Foundation of China (31161140345, 31400182, and 31400192), Minzu University of China (YLDX01013, and 2015MDTD16C), Ministry of Science and Technology of China (2005DKA21006, 2008FY110400, and 2012FY110300), Ministry of Education of China and State Administration of Foreign Experts Affairs of China (B08044).

\section{References}

[1] C.L. Long and H.C. Song, Biodiesel Plants in China, Science Press, Beijing, 2012.

[2] Information on http://biodiesel.org/

[3] The State Council of China, Announcement to accelerate production development of oil-bearing woody plants, Guo Fa Ban [2014]68, The State Council of China (January 13, 2015).

[4] Z. Wang, J. Yang, Y. Tan, G.W. Hu, C.L. Long, Comprehensive evaluation of woody oil-bearing plants in Yunnan as sources for biodiesel, Plant Diversity and Resources 35(2013): 630-640. 
[5] J. Yang, Z. Wang, Y. Su, Y. Tan, C.L. Long, Oil contents and fatty acids compositions of seed oils from three Michelia species plants, China Oil and Fats 38(2013): 89-91.

[6] B. Meng, C.L. Long, Z.Y. Cheng, Y. Liu, Tissue culture and rapid propagation of large-fruited hodgsonia [Hodgsonia macrocarpa (Blume) Cogn.], Plant Physiology Communications 43(2007): 747.

[7] H. Qin, S.Q. Song, C.L. Long, H.Y. Cheng, Tissue culture and plant regeneration of Jatropha curcas (Euphorbiaceae), Acta Botanica Yunnanica 28(2006): 649-652.

[8] P.M. Qu, C.L. Long, Z.Y. Cheng, D. Yang, Tissue culture and rapid propagation of Cyperus esculentus L. var. sativus Boeck, Plant Physiology Communications 43(2007): 331.

[9] P.M. Qu, Z.Y. Cheng, C.L. Long, M.H. Su, D. Yang, Comprehensive development of chufa (Cyperus esculentus L. var. sativus), China Oil and Fat 32(2007): 61-63.

[10] P.M. Qu, Z.Y. Cheng, C.L. Long, M.H. Su, D. Yang, Development potentials of chufa for biodiesel production, Renewable Energy Resources 26(2008): 106-109.

[11] X. Wang and C.L. Long, Investigation and evaluation of Jatropha curcas (Euphrbiaceae) resource in Yunnan Province, Acta Botanica Yunnanica 31(2009): 455-460.

[12] Z.Y. Xiang, S.Q. Song, G.J. Wang, M.S. Chen, C.Y. Yang, C.L. Long, Genetic diversity of Jatropha curcas (Euphrobiaceae) collected from southern Yunnan, detected by inter-simple sequence repeat (ISSR), Acta Botanica Yunnanica 29(2007): 619-624.

[13] H.J. Guo and C.L. Long, Biodiversity of Yunnan, Yunnan Science \& Technology Press, Kunming, 1998.

[14] G.H. Xie, Classification of biofuel plants and their transformation. Journal of China Agricultural University 16(2011): 1-7.

[15] K. Openshaw, A review of Jatropha curcas: an oil plant of unfulfilled promise. Biomass and Bioenergy 19(2000): 1-15.

[16] X.F. Tan, G.X. Jiang, F.Y. Tan, W.G. Zhou, P.H. Lü, K.M. Luo, H.Z. Sun, C.N. Wang, J.L. Ma, J.L. He, W.H. Liang, Y. Huang, Research report on industrialization development strategy of Vernicia fordii in China. Nonwood Forest Research 29(2011): 1-7. 